\title{
EFEK KONSENTRASI PARTIKEL PLASTIK TERHADAP PERTUMBUHAN DAN KELANGSUNGAN HIDUP IKAN BAWAL BINTANG (TRACHINOTUS BLOCHII)
}

\author{
Tengku Said Razai ${ }^{1^{*}}$, Try Febrianto ${ }^{2}$, Imam Pangestiansyah Putra ${ }^{3}$ \\ ${ }^{1}$ Program Studi Budidaya Perairan, Universitas Maritim Raja Ali Haji, Tanjungpinang, Indonesia, \\ ${ }^{2}$ Program Studi Ilmu Kelautan Universitas Maritim Raja Ali Haji, Tanjungpinang, Indonesia \\ ${ }^{3}$ Marine chemistry Laboratory Universitas Maritim Raja Ali Haji, Tanjungpinang, Indonesia \\ *Koresponden E-mail: tengkusaidrazai@gmail.com
}

\begin{abstract}
Plastic pollution / waste has an impact that will disturb the stability of the ecosystem, especially aquatic organisms such as fish. The main source of plastic contamination comes from household waste that is not managed properly, especially in coastal areas that make the sea as a place of final discharge. Plastic pollution is currently the main problem that is accepted by the environment, especially water. Plastic will dissolve in the waters and will form small sizes (micro-plastic) impacting biota, including fish. Fish including aquatic organisms that can not distinguish between food and plastic particles clearly, thus providing an effect on digestion and growth. The results showed the growth rate of silver Pompanoo with the highest plastic concentration will cause slower growth, the control treatment is the best growth yield compared to treatments that have a plastic content mixed with feed. Growth of weights with the highest concentration of plastic particles is $0,48 \mathrm{gr} /$ week, length growth is $0.75 \mathrm{~cm} /$ week, and survival is $69.17 \%$ and shows the growth and survival rates are worse or there is a tendency to worsen with an increase in the concentration of plastic contamination. Plastic particles consumed by fish are not digested properly and can even cause the growth response of fish to be slow even to death.
\end{abstract}

\section{Keywords: Plastic Particles, Growth, Survival, Silver Pompanoo}

Pencemaran plastik saat ini merupakan problem utama (main problem) yang diterima oleh lingkungan, terutama perairan. Berdasarkan data yang dihimpun dari penelitian Brate et al. (2017) Produksi global plastik mencapai 322 juta ton pada tahun 2015 yang pada akhirnya menghasilkan produk limbah ketika barang mencapai akhir penggunaannya. Plastik akan terlarut di perairan dan akan membentuk ukuranukuran kecil (micro-plastik) berdampak pada biota. Plastik yang terlarut pada lingkungan perairan akan mengambang, terlarut, serta mengendap ke dasar perairan. Plastik yang terlarut dan mengambang akan dikonsumsi oleh biota pelagis.

Dampak plastik terhadap kehidupan ikan di perairan tidak bisa dihindarkan mengingat banyaknya limbah plastik yang terabsobsi ke perairan. Dilaporkan dari penelitian Pinheiro et al. (2017) bahwa terdapat 34 spesies ikan yang terpapar limbah plastik terutama pada family Callichthyidae, Centrarchidae, Characidae, Clupeidae, Cyprinidae, Fundulidae, Ictaluridae, Percidae, dan Poeciliidae. Penelitian Critchell et al. (2018) juga melaporkan bahwa jenis ikan karang Acanthochromis polyacanthus dapat mengkonsumsi plastik yang tersebar diperairan dengan ukuran antara 125-300 m. Efek mengkonsumsi partikel plastik ini menyebabkan kerusakan dan penyumbatan pada sistem pencernaan. Pengaruh partikel plastik sangat mungkin dapat menghambat pertumbuhan ikan-ikan yang hidup diperairan, termasuk pada jenis ikan konsumtif yang saat ini telah banyak di budidayakan di perairan KEPRI. Salah satu jenis ikan yang banyak dibudidayakan dan menjadi komoditas ekonomis yakni ikan bawal bintang (Tranchinotus blochii).
Kontaminan partikel plastik yang terdapat di perairan juga akan berpengaruh terhadap kehidupan ikan Bawal Bintang terutama dapat mempengaruhi sistem pencernaannya yang akan berimbas pada kondisi morfologis dan fisiologisnya. Penelitian terkait dengan Efek Partikel Plastik Terhadap Respon Pertumbuhan dan Kelangsungan hidup Ikan Bawal Bintang (Trachinotus blochii) akan memberikan informasi terkait dengan pengaruh partikel plastik terhadap pertumbuhan dan kelangsungan hidup sehingga dapat menggambarkan efek yang diterima oleh ikan jika terpapar oleh limbah plastik di lingkungan perairan. Penelitian ini bertujuan untuk mengetahui efek pemberian partikel plastik pada pakan terhadap respon pertumbuhan Ikan Bawal Bintang (Trachinotus blochii).

\section{BAHAN DAN METODE}

Penelitian dilaksanakan di Laboratorium Akuakultur, Fakultas Ilmu Kelautan dan Perikanan, Universitas Maritim Raja Ali Haji (FIKP-UMRAH), pada bulan Januari-Maret 2012. Alat-alat yang digunakan dalam penelitian ini antara lain; akuarium bervolume $50 \mathrm{~L}$, pipet tetes, botol semprot, sifon, nampan, gelas ukur, timbangan analitik, mistar/penggaris, multi tester, refractometer, thermometer, alat tulis, kamera, mikroskop. Sedangkan bahan yang digunakan yakni; ikan uji, air laut, partikel plastik halus, pakan, telur. Wadah yang digunakan untuk pemeliharaan ikan yakni akuarium dengan ukuran tinggi $30 \mathrm{~cm} \times$ lebar $30 \mathrm{~cm} \times$ panjang $50 \mathrm{~cm}$ sebanyak 9 unit. Untuk masing perlakukan dilakukan pengulangan sebanyak 3 kali (3 wadah). 
Wadah yang digunakan diberi label perlakuan ulangan secara acak. Sebelum dilakukan penelitian wadah di bersihkan dan dicuci serta disterilkan. Setelah wadah terisi oleh air, kemudian dilengkapi dengan aerasi, dan didiamkan selama 1 hari.

Benih ikan bawal bintang yang akan diuji, diaklimatisasi terlebih dahulu sebelum dilakukan perlakuan. Proses aklimatisasi dilakukan selama 2 hari. Benih ikan yang digunakan dalam penelitian ini adalah benih dengan panjang tubuh rata-rata $7 \mathrm{~cm}$ dan bobot tubuh rata-rata 4 gram, berjumlah 120 ekor, dalam tiap-tiap aquarium 10 ekor benih ikan yang sehat dan tidak terserang penyakit. Bening diadaptasi terlebih dahulu selama 3 hari tidak diberi pakan.

Rancangan penelitian yang disusun ini menggunakan Rancangan Acak Lengkap (RAL) dengan 4 perlakuan dan 3 ulangan dengan padat tebar yang sama (10 ekor) Faktor perlakuan adalah perbedaan konsentrasi partikel plastik yang dicampurkan dalam pakan komersil ikan bawal bintang mengacu pada konsentrasi Critchell dan Hoogenboom (2018).

Perlakuan K : Kontrol (tanpa partikel plastik)

Perlakuan A : Konsentrasi plastik rendah $(0,025$ mg/pakan)

Perlakuan B : Konsentrasi plastik tinggi $(0,083$ mg/pakan)

Masing-masing konsentrasi plastik dimasukkan kedalam wadah budidaya bawal bintang bersamaan dengan pemberian pakan. Selama pemeliharaan, bawal bintang diberi pakan berupa pellet MEGAMI dengan FR (Feeding Rate) sebesar 2-3\% dan frekuensi pemberian pakan dua kali sehari pagi (09.00 WIB) dan sore (15.00 WIB) (Putra et al. 2017).

\section{Data Analysis.}

Data yang diamati pada penelitian ini yakni data pertumbuhan bobot ikan, panjang mutlak, serta kelangsungan hidup ikan bawal bintang yang diberikan perlakuan konsentrasi plastik yang berbeda.

Kelangsungan Hidup (Surviving Rate); Kelangsungan hidup ikan dihitung berdasarkan rumus sebagai berikut :

$$
\mathbf{S K}=\left(\frac{N t}{N 0}\right) \times 100 \%
$$

Keterangan $=\mathrm{SR}:$ Kelangsungan hidup $(\%) ; \mathrm{Nt}$ : Jumlah ikan yang hidup pada akhir penelitian (ekor); No : Jumlah ikan pada awal penelitian (ekor)

Bobot Mutlak; Penambahan bobot tubuh ikan dihitung berdasarkan rumus sebagai berikut:

$$
\text { W=W_t- W_0 }
$$

Keterangan $=\mathrm{W}:$ Pertumbuhan berat (gr); Wt : Berat ikan pada waktu akhir (gr); Wo : Berat ikan pada waktu awal (gr)

Panjang Mutlak; Pertumbuhan Panjang dihitung berdasarkan rumus sebagai berikut:

$$
\mathbf{L}=\mathrm{L} \_\mathrm{t}-\mathrm{L} \_0
$$

Keterangan $=\mathrm{L}$ : Pertumbuhan panjang $(\mathrm{cm}) ; \mathrm{Lt}$ : Panjang ikan pada waktu akhir (cm); Lo : Panjang ikan pada waktu awal (cm)

\section{HASIL}

Pengamatan pertumbuhan ikan bawal bintang meliputi penambahan panjang mutlak, penambahan bobot, serta kelangsungan hidup diamati setiap minggu. Pertumbuhan masing-masing perlakuan didata dan kemudian dianalisis, kondisi fisiologis dan morfologis ikan uji diperlukan untuk mendukung analisis dan pembahasan hasil data yang diperoleh. Dari hasil penelitian yang dilakukan menunjukkan bahwa masing-masing perlakuan memberikan respon pertumbuhan yang berbeda. Pola penambahan bobot, panjang, serta kelangsungan hidup terdapat perbedaan pada masing-masing perlakuan (Gambar 1).

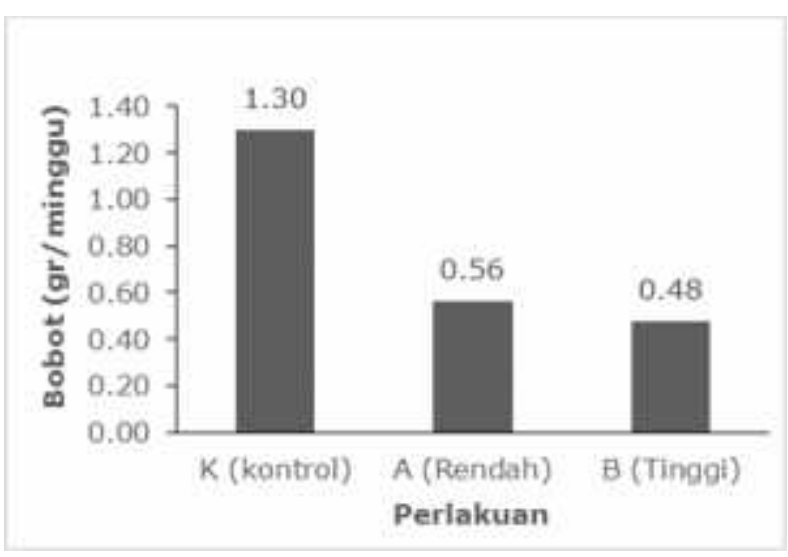

(a)

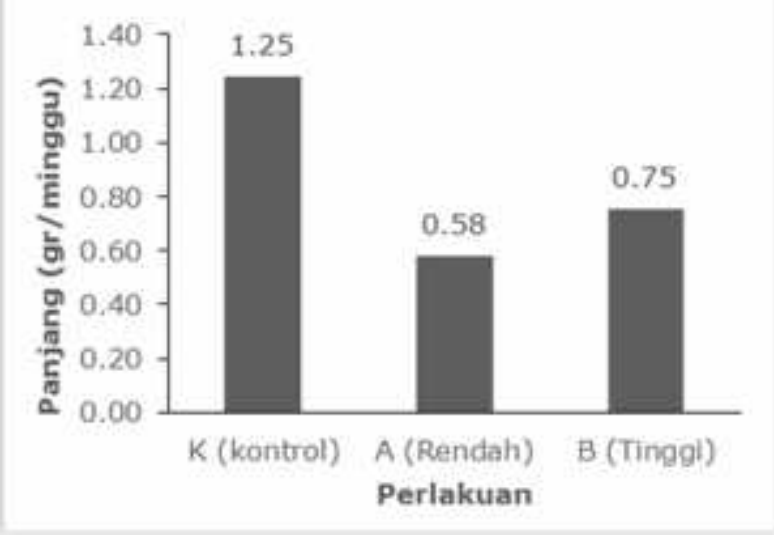

(b) 


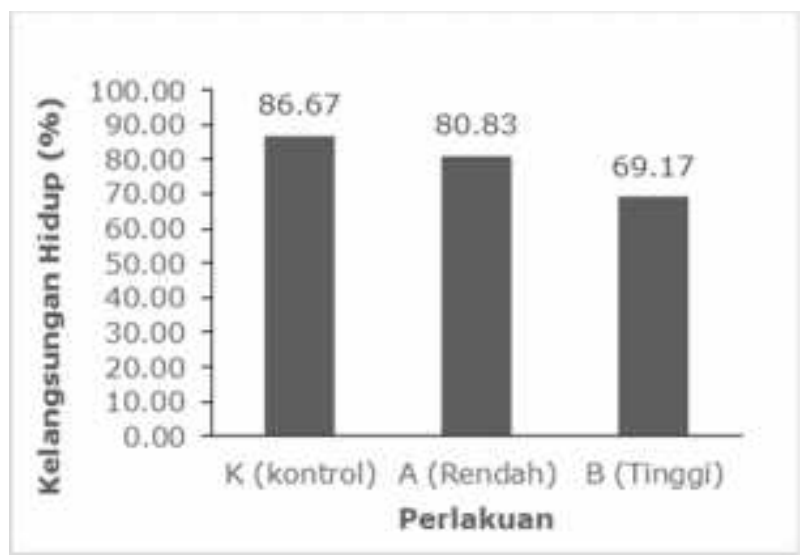

(c)

Gambar 1. Pertumbuhan bobot (g); Pertumbuhan panjang (cm); Tingkat kelangsungan hidup (\%) ikan bawal bintang

\section{PEMBAHASAN}

Data yang dikumpulkan selama pengamatan 4 minggu menunjukkan bahwa pada perlakuan ikan bawal bintang yang tanpa partikel plastik (kontrol) memperoleh penambahan bobot tertinggi dengan ratarata mencapai $1,3 \quad 0,58 \mathrm{gr} / \mathrm{minggu}$. Sedangkan pada perlakuan B (pakan dengan konsentrasi partikel plastik tinggi) menunjukkan penambahan bobot terendah yakni hanya $0,480,15 \mathrm{gr} / \mathrm{minggu}$. Pada perlakuan A (pakan dengan konsentrasi partikel plastik rendah) memperoleh penambahan bobot sebesar 0,56 0,35 gr/minggu. Pertumbuhan bobot ikan bawal bintang pada umumnya berkisar antara 0,20-0,80 gr/minggu (Kalidas et al. 2012). Dalam penelitian lain dilaporkan bahwa perkembangan bobot ikan bawal bintang ratarata sebesar 0,81 gr/minggu. (Alejos dan Serrano 2018). Jika mengacu penelitian Chaves et al. (2011) pertumbuhan ikan bawal bintang rata-rata sebesar 0,88 gr/minggu.

Penambahan panjang mutlak ikan bawal bintang yang di kultur tertinggi pada perlakuan pakan yang tidak diberi partikel plastik (kontrol) dengan pertumbuhan sebesar 1,25 0,53 cm/minggu. Perlakuan dengan konsentrasi partikel plastik rendah (A) merupakan yang terendah hanya dengan pertumbuhan panjang sebesar $0,58 \quad 0,26 \mathrm{~cm} / \mathrm{minggu}$. Hidayat et al. (2019) melakukan penelitian terkait dengan pertumbuhan panjang ikan bawal bintang dan memperoleh nilai antara 7,0-7,3 cm dalam waktu 3 bulan atau 0,58-0,6 cm/minggu. Pertumbuhan panjang ikan bawal bintan yang diberi pakan partikel plastik memiliki nilai yang lebih rendah dibandingkan dengan pakan tanpa partikel plastik.

Tingkat kelangsungan hidup/surviving rate juga memberikan respon yang baik pada perlakuan kontrol tanpa partikel plastik dengan nilai kelangsungan hidup mencapai 86,67\%. Pada perlakuan A (konsentrasi partikel plastik rendah) memperoleh nilai kelangsungan hidup sebesar 80,83\%, sedangkan pada perlakuan B (konsentrasi partikel plastik tinggi) kelangsungan hidupnya hanya sebesar $69,17 \%$.
Dalam uji beda nyata (anova one way) menunjukkan bahwa dari 3 perlakuan pada respon pertumbuhan panjang, bobot, serta kelangsungan hidup masing-masing memperoleh nilai F-hitung yang lebih besar dibandingkan F-tabel pada skala kepercayaan 0,05 . Respon pertumbuhan bobot nilai fhitungnya sebesar 2,77. Pada respon pertumbuhan panjang memiliki nilai f-hitung sebesar 0,58 serta pada kelangusngan hidup memperoleh nilai f-hitung 0,32. Kesipulannya, bahwa masing-masing perlakuan penelitian memiliki perbedaan signifikan pada pakan yang dicampurkan oleh partikel plastik (A dan B) dengan pakan yang tidak diberikan partikel plastik (kontrol).

Dari hasil penelitian menunjukkan bahwa partikel plastik mempengaruhi respon pertumbuhan ikan bawal bintang. Hal ini dibuktikan bahwa perlakuan B dengan konsentrasi plastic tertinggi memperoleh tingkat pertumbuhan ikan yang terendah. Kondisi ini menjelaskan bahwa secara umum, ikan tidak dapat membedakan antara nutrisi dan partikel plastic yang berhamburan di perairan. Hal ini dijelaskan juga oleh penelitian Pinheiro et al. (2017) plastik telah mengkontaminasi sebanyak 600 spesies ikan, pada umumnya plastik dikonsumsi oleh ikan dengan ukuran kecil/microparticle secara tidak sengaja dan bersamaan dengan mengkonsumsi makanan. Solomon dan Planisami (2016) menyatakan bahwa konsumsi plastik umumnya terjadi pada ikan stadia larva yang bersifat planktivorous, dan mengira plastik sebagai salah satu jenis plankton yang dapat dikonsumsi oleh ikan.

\section{SIMPULAN}

Respon pertumbuhan ikan bawal bintang yang diberikan perlakuan pakan dengan partikel plastik memiliki nilai pertumbuhan yang berbeda. Namun secara keseluruhan baik pada respon pertumbuhan bobot, panjang, serta kelangsungan hidup perlakuan kontrol (tanpa partikel plastik) merupakan parlakuan yang memiliki respon pertumbuhan lebih tinggi. Artinya pemberian partikel plastik dan kemudian dikonsumsi oleh ikan, memberikan efek yang tidak baik terhadap pertumbuhan ikan bawal bintang.

\section{DAFTAR PUSTAKA}

Alejos. M. S, Serrano. A. E. 2018. Continuous illumination improves growth and survival in the early stage of snubnose pompano Trachinotus blochii. AACL Bioflux 11 (5) : 1557-1563.

Arrokhman. S, Abdulgani, Hidayati. D. 2012. Survival Rate Ikan Bawal Bintang (Trachinotus blochii) dalam Media Pemeliharaan Menggunakan Rekayasa Salinitas. Jurnal Sains dan Seni 1 (1) : 32-35.

Brate. I. L, Huwer. B, Thomas. K. V, Eidvoll. D. P, Halsband. C, Almroth. B. C, Lusher. A. 2017. 
Micro-and macro-plastics in marine species from Nordic waters. Rosendahls : $102 \mathrm{hlm}$.

Chaves. H. M, Fang. A. L, Carandang. A. A. 2011. Effect of Stocking Density on Growth Performance, Survival and Production of Silver Pompano, Trachinotus blochii, (Lacepede, 1801) in Marine Floating Cages. Asian Fisheries sciences 24 : 321-330.

Crithell. K, Hoogenboom. M. O. 2018. Effects of microplastic exposure on the body condition and behaviour of planktivorous reef fish (Acanthochromis polyacanthus). Researce Article March : 1-19.

Food And Agriculture Organization Of The United Nations (FAO). 2017. Microplastics in fisheries and aquaculture Status of knowledge on their occurrence and implications for aquatic organisms and food safety.

Gerber. K. 2015. Effects Of Plastic Pollution On Deep Ocean Biota and Ecosystems. [thesis]. University of Oregon. $28 \mathrm{hlm}$.

Hidayat. K, Yulianto. H, Ali. M, Noor. N.M, Putri. B. 2019. Performance of snubnose pompano Trachinotus blochii in both monoculture and polyculture within green mussels Perna viridis cultivated on raft system. Depik 8 (1) : 1-8.

Jayakumar. A. B. N, Tamilmani. G, Sakthivel, Kalidas. C, Kumar. P. R, Anbarasu. M, Sirajudeen. S, Balamuguran. V, Jayasingh. M, Gopakumar. G. 2012. Larviculture and seed production of the silver pompano, Trachinotus blochii (Lacepede, 1801) for the first time in India. Journal of Indian Fish 59 (3) : 83-87.

Kalidas. C, Sakthivel. M, Tamilmani. G, Kumar. P. R, Nazar. A. B, Jayakumar. R, Balamurugan, Ramkumar, Premjothi, Gopakumar. G. 2012. Survival and growth of juvenile silver pompano Trachinotus blochii (Lacepede, 1801) at different salinities in tropical conditions. Indian Fish 59 (3) : 95-98.

Liboiron. M. 2016. Redefining pollution and action: The matter of plastics. Journal of Material Culture 21 (1) : 87-110.

Marzuqi. M. Anjusary. D. N. 2013. Nutrient Digestibility Feed With Different Levels Of Protein And Lipid On Coral Rock Grouper (Epinephelus Corallicola) Juvenile. Jurnal Ilmu dan Teknologi Kelautan Tropis 5 (2) : 311-323.

Pinheiro. C, Oliveira. U, Veira. M. 2017. Occurrence and Impacts of Microplastics in Freshwater Fish. Journal of Aquaqulture and Marine Biology 5 (6) : 2-5.

Putra. W. K. A, Handrianto. R, Razai. T. 2017. Maturation of the Silver Pompano (Trachinotus blochii) Gonad by Hormon Human Chorionic Gonadotropin (hCG) and Pregnant Mare Serum Gonadotropin (PMSG). Jurnal Perikanan Universitas Gadjah Mada 19 (2) : 75-78.

Putri. A. K, Anggoro. S, Djuwito. 2014. Osmotic Performance Rate and Development of Silver
Pompano Seeds Biomass (Trachinotus blochii) which Cultivated on Media with Different Salinity. Journal Maquares 4 (1) : 159-168.

Solomon. O. O, Palanisami. T. 2016. Microplastics in the Marine Environment: Current Status, Assessment Methodologies, Impacts and Solutions. Journal Pollut Eff Cont 4 (2) : 2-13.

Wijaya. A, Damayanti. A. A, Astriana. B. H. 2018. Pertumbuhan Dan Efisiensi Pakan Ikan Bawal Bintang (Trachinotus blochii) Yang Dipuasakan Secara Periodik. Jurnal Perikanan 8 (1) : 1-7. 